\title{
Status and Potential of Resource Recovery from Municipal Solid Waste in Kathmandu Valley, Nepal
}

\author{
Dhundi Raj Pathak ${ }^{1,2}$ \\ ${ }^{1}$ Director/SWM Specialist, Engineering Study \& Research Centre, Kathmandu, Nepal \\ ${ }^{2}$ Visiting Faculty, Tribhuwan University, Kathmandu, Nepal \\ Email: drpathak@esarcnepal.com
}

\begin{abstract}
Current waste management strategies are shifting from waste disposal to recycling and recovery and are considering waste as a potential new resource. This paper aims to quantify reusable and recyclable fractions with status of material recovery from municipal solid waste (MSW) in Kathmandu Valley of Nepal. 550 households, 110 institutions and 110 commercial establishments were sampled to compute the generation, composition and quantify reusable and recyclable fraction of solid waste. In addition, 120 scrap shops were surveyed randomly from Kathmandu Valley to estimate the amount of resource recovered for economic benefits. As per results, the average per capita MSW generation can be estimated at range of $0.25 \mathrm{~kg}^{\mathrm{day}}{ }^{-1}$ to 0.47 $\mathrm{kg} \mathrm{day}^{-1}$ in municipalities of Kathmandu Valley. Based on these generation rates and population for the year 2011, the total MSW generation of the five municipalities of Kathmandu Valley was estimated to be 620 metric tonnes day ${ }^{-1}$. The major content of reusable and recyclable materials in MSW comprised with an average of $44 \%$ that is equivalent to 271 metric tonnes day ${ }^{-1}$ among which only $52 \%$ (i.e. 140 metric tonnes day $^{-1}$ ) of these materials were found to be recovered during survey. The key materials that have been recovered are papers, plastics, metals, glasses, and batteries. Recovery of reusable and recyclable materials not only helps to minimize the quantity of solid waste for land filling, but also provides a potential source of livelihood for the urban poor.
\end{abstract}

Keywords: Resource recovery, Municipal solid waste, Scrap shop, Recycling, Kathmandu

\section{Introduction}

Urban population growth and economic development, a crucial consideration for municipal solid waste (MSW) generation, not only accelerate consumption rates but also increase waste generation (Alamgir et al., 2005). Unplanned urbanization and rapid migration of people leads to significant quantity of solid waste in all major cities of developing countries, including Nepal. Kathmandu Valley, an urbanized cultural, political, and economic hub of Nepal, with high population density, is facing intensified solid waste problems. Kathmandu Valley's population which increased from 0.41 million in 1954 to 1.65 millions in 2001 and further to approximately 3 million in 2011 (Pathak et al., 2013) is an example of rapid urbanization.

Solid waste management (SWM) has become one of the major concern for all municipalities and cities of Nepal, including Kathmandu Valley. At the same time, a concept of resource recovery from MSW and its economic benefits with legal provisions of sorting waste at sources has been introduced in Nepal. Though, wider understanding on solid waste as a resource is not a new concept (Gutberlet, 2008), but, this idea and issues related on sustainable SWM are becoming 
more popular day by day around the world. Over the last few years, waste management strategies are shifting from waste disposal to recycling and recovery and are considering waste as a potential new resource (Huysman et al., 2015). Recovery of reusable and recyclable materials not only helps to minimize the quantity of solid waste for land filling, but also provides a potential source of livelihood for the urban poor. This was true for medieval cities as well as rapidly growing industrial cities of Europe and North America in the 19th century, and also applies to developing countries today (Wilson, 2007). Globally, there are more than two million informal waste pickers in recycling industries engaged in various areas of waste recovery (Hoornweg and Bhada-Tata, 2012). This sector has achieved considerable gains in terms of recycling rates to the tune of $20 \%$ to $30 \%$ in low income countries which has helped local government units or authorities save $20 \%$ in local waste management expenses (Velis et al., 2012). It has been estimated that as much as $2 \%$ of the urban population in Asia and Latin America depend on waste picking for all or part of their livelihood (Medina, 2000). Linzner and Salhofer (2014) reported an interval of approximately $0.56 \%-0.93 \%$ of the urban population or 3.3-5.6 million people involved in informal waste collection and recycling activities in urban China. According to Serrona et al. (2014), the number of informal waste workers range from 5000 to 7000 in Metro Manila in the Philippines. Asim et al. (2012) reported that 325 informal workers in Southwestern Allama Iqbal Town of Lahore, Pakistan, which has a population of over 120,000 people, sort out about 525 metric tonnes of recyclables solid waste per month which generate an income of about US\$ 30,875 per month.

Currently, no formal municipal waste recovery and recycling programs exist in municipalities of Nepal. However there are substantial numbers of informal waste pickers and scrap shops in Nepal, the majority of which operate in urban areas like Kathmandu Valley where reusable and recyclable materials abound. In Kathmandu Valley alone, their number ranges from 10000 to 15000 based on estimates (Pathak, 2013; PRISM, 2013). The reusable and recyclable materials from sources such as household, institution and commercial establishment are mainly collected through these informal waste workers for paper, plastic utensils, metals and glass and sell to local scrap shops for their livelihood.

Moreover, the mandatory provision of source segregation of waste and promotion of 3Rs (Reduce, Reuse, and Recycle) approach has been introduced in Nepal through new solid waste management act (SWMA) promulgated in July 2011. Mandatory source separation and recycling initiatives induce citizens to change their living habits, segregate refuse at source and increase the current recycling rate (Gallardo, et al., 2010). Based on a case study on Haulien County in Taiwan, it was found that the recycled material fraction of MSW generated in 2001 was 6.8\% which increased to $32.4 \%$ in 2010 when imposed source separation and recycling initiatives (Chang et al., 2013). Though this may increase costs in comparison with the current collection scheme, the possibility of returning approximately $90 \%$ of the wastes to productive cycle in the form of recycled materials would undoubtedly represent direct benefits for the municipality by reducing the volume of waste that needs to be disposed of at landfill, increased service life of landfill site, resulting reinforcement of recycling as an economic activity (Mancini et al., 2007). Recycling has also environmental benefits at every stage in the life cycle of a consumer product i.e. from raw material to its final disposal. In addition to economic and environmental benefits, advantages in industrial competitiveness seem in two core ways. First, materials recovered by 
waste pickers are generally cheaper than virgin materials. Second, recycling requires less energy than obtaining virgin raw materials, lowering industry's operating costs (Medina, 2005, 2008). In developing countries, it is acknowledged that the recovery of materials such as iron, steel, copper, lead, paper, plastic and glass decrease the investment in importing these materials and save energy (Kocasoy, 2001); however, materials recovery is hardly applied due to poor public awareness and lack of proper sorting of waste at sources. A comprehensive data and information on SWM, including quantity and composition of MSW, is essential to quantify the actual amount of reusable and recyclable fractions that can be recovered as a valuable resources. A few studies, in the past, on MSW generation and composition have been conducted in the municipalities of Kathmandu Valley (SWMRMC, 2004; Nippon Koei and Yachiyo Engineering, 2005; Dangi et al., 2008, 2011). Most of them were either limited to KMC or lacked consistent methodology used in the studies.

Informal waste recovery and recycling studies were carried out in many developing countries, such as India (Agarwal et al., 2005; Hayami et al., 2006), Indonesia (Sasaki and Araki, 2014; Sembiring and Nitivattananon, 2010), Mexico ( OjedaBenitez et al., 2002), Nigeria (Agunwamba, 2003; Nzeadibe, 2009), Pakistan (Asim et al., 2012), Tanzania (Kaseva and Gupta, 1996) and Vietnam (Kawai et al., 2012; Mitchell, 2008). Nippon Koei and Yachiyo Engineering (2005) carried out marketing survey on recyclable materials in Kathmandu Valley were data collection was based on information given by main (wholesale) suppliers. However, as far as we are aware of, comprehensive and scientific study on the latest status of municipal waste generation, compoposition, resource recovery potential, and amount of materials currently recovered from MSW and their economic value in Kathmandu Valley have not been carried out yet. So, the objectives of this study are:

(1) to conduct a MSW generation and composition study in Kathmandu Valley,

(2) to quantify the resource recovery potential from MSW, and

(3) to carry out a separate study to estimate the quantity of the reusable and recyclable materials that are actually being collected in the municipalities of Kathmandu Valley

\section{Materials and Methods}

\section{Study area}

First, a study on MSW generation and composition was conducted to estimate amount of waste and its composition in five municipalities within Kathmandu Valley. Second, another survey was carried out with scrap (kawadi) shops to identify the amount of recovered materials from MSW stream in five municipalities of Kathmandu Valley. In addition, neighboring scrap shops of newly created municipalities (old VDCs) near the boundary of earlier municipalities were also considered. Based on estimates, 700 to 800 scrap shops were reported in Kathmandu Valley (Pathak, 2013; PRISM, 2013). Since, most of the scrap shops are located in KMC and LSMC, the survey was focused in these cities, especially, KMC as shown in Figure 1. 


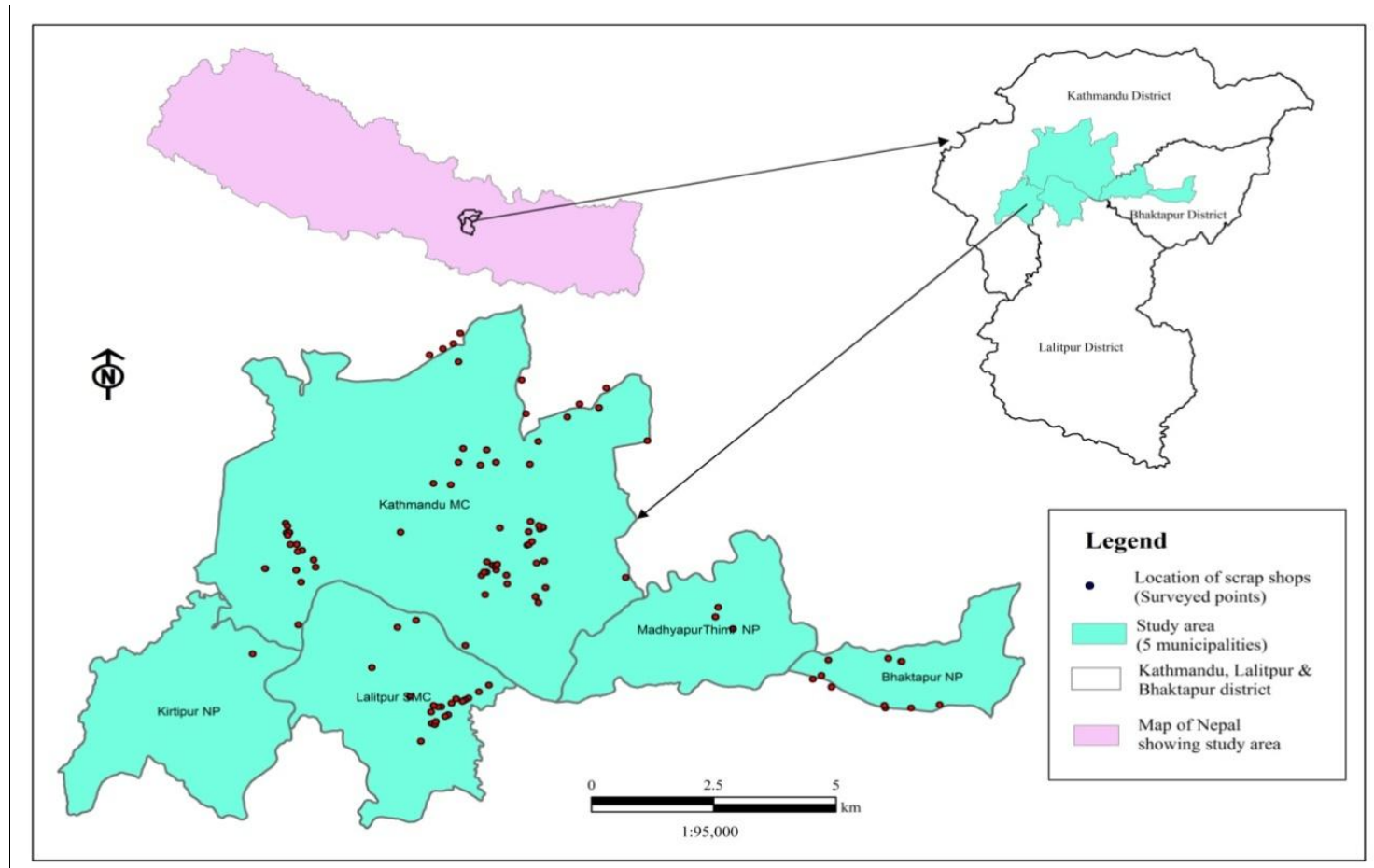

Figure 1. Study area and location of surveyed scrap (kawadi) shops

\section{Study design and data collection}

Sampling Design: The survey on MSW generation and composition covered all five municipalities with sample size of 550 households, 110 institutions (schools and offices), and 110 commercial establishments (shops, hotels, and restaurants). Though, other potential sources of waste generation, such as industries and health institutions, were not covered due to their special characteristics.

The sample size for each municipality was determined based on household numbers (i.e., greater the household number; greater the sample size). However, the minimum sample size was set at 50 households. Moreover in second stage, proportional numbers of wards were selected from each municipality based on the rural-urban set-up, income level, population density in consultation with concerned municipal officials. The number of sample wards varied according to the size of the municipality. One ward was selected for every 10 households: for example, if 100 households are to be selected from a municipality, then it included ten wards, each with 10 households. In this study, 200, 150 and 100 households were selected in KMC, LSMC, and Bhaktapur Municipality (BM) respectively, while minimum 50 households were selected for other two municipalities; Madhyapur Thimi Municipality (MTM) and Kirtipur Municipality $(\mathrm{KM})$. Furthermore, in third stage, households in each sample ward were selected randomly. Sampling for the selection of institutions and commercial establishments were done in similar manner as followed in household survey. 5 schools and 5 offices were selected from Kirtipur and Madhyapur Thimi municipalities while 20 offices and 20 schools from KMC, 15 schools and 15 offices from LSMC and 10 offices and 10 schools were sampled from BM. In general, wards selected for household survey were selected for sampling of institutions and commercial 
establishments. One school and one office from each ward were selected, except for wards where there are no schools or offices. In such case, two or more schools or offices were sampled from a single ward. Similarly, 110 shops, hotels, and restaurants were selected for survey, which spread across five municipalities of Kathmandu Valley. Sampling for the selection of commercial establishments was done in similar manner as the institutions survey. One shop and one hotel or restaurant was randomly selected from each ward. The solid waste composition survey classified the waste into the following eight categories: bio-degradable, plastics, papers, textile, rubber and leather, metals, glass, and others (inert materials etc.)

Further, a separate survey was conducted to estimate the amount of recovered materials from whole study area in which a total of 120 scrap shops were randomly selected. Due to higher economic activities in KMC, large numbers of scrap shops are located here and most of these shops for survey were selected from KMC. Although, there are many types of reusable and recyclable materials in solid waste stream, some of the more imperative materials like, paper (newspaper, books, note books, cartoons), plastics (plastic utensils, plastic sack, PET bottles), metals (iron, tin, aluminum), glass and few other materials (battery) were considered for survey.

Field study: Survey on waste generation and composition was conducted in April to May 2012 during dry season. Due to difficulty on waste handing from more than 550 households, 110 institutions and 110 commercial establishments with limited resources and time, as well as based upon the findings of Nippon Koei and Yachio Engineering (2005) and Dangi et al. (2008) in the municipalities of Kathmandu Valley, we adopted a single day sampling of waste. On the day before physical sampling, it was informed to each household, institutional and commercial establishment that their wastes generated in 24-hour period would be analyzed by providing waste collection bags. The waste was collected the next day to measure quantity (in wet weight basis) of the eight different categories.

Further, a seperate survey was carried out during the period of December 2012 to January 2013 to estimate the status of recovered recyclable and reusable waste materials and their economic value. The study was done only for the imperative materials those are being collected by scrap shops. Pre-designed questionnaires were used to get the amount of recovered materials in each scrap shops.

Data analysis: Upon completion of the field survey on waste generation and comopsition, data were analyzed using Microsoft (MS) Excel. Consistency and extreme value were checked before analysis. After the analysis, data were presented in tabular form with necessary charts and graphs, developed for MSW of each municipality in Kathmandu Valley. A weighted average MSW generation and composition of all the municipalities was calculated to estimate materials recovery potential in Kathmandu Valley. Further, total amount of recovered materials in Kathmandu Valley were estimated analyzing the data obtained from survey on scrap shops.

\section{Results and Discussions}

\section{MSW Generation}

The total sample size of 550 households from five municipalities, varying from minimum 50 households to 200 households, gave an average per capita household waste generation figure at 
the range of $0.14 \mathrm{~kg} \mathrm{day}^{-1}$ in MTM to $0.23 \mathrm{~kg} \mathrm{day}^{-1}$ in KMC. For each surveyed households, the per capita waste generation was computed by dividing the total produced waste by total number of residents living in that household on that particular day. The per capita and total household waste generation in each municipality of Kathmandu Valley is given in Table 1. The per capita household waste generation of Kathmandu Valley's municipalities including KMC's waste generation calculated in this study appeared comparable to previous studies (Dangi et al., 2008; Nippon Koei and Yachio Engineering, 2005). For example, this study revealed an average per capita household waste generation rate of KMC as $0.23 \mathrm{~kg} \mathrm{day}^{-1}$, which is level-headed to the data presented by Nippon Koei and Yachio Engineering (2005). In their study, the majority of households among the 400 households sampled in KMC yielded generation rate of 0.10 to 0.15 $\mathrm{kg} \mathrm{day}^{-1}$ with an average generation rate of $0.25 \mathrm{~kg} \mathrm{day}^{-1}$ in their frequency plot and is in general agreement with the results of our survey. Similarly, Dangi et al (2008) reported the average per capita waste generation rate among the 200 households sampled in KMC was $0.16 \mathrm{~kg} \mathrm{day}^{-1}$, with the lower and upper bounds of 0.14 and $0.19 \mathrm{~kg} \mathrm{day}^{-1}$.

The total commercial and institutional waste was calculated in each municipality which is also given in Table 1 . The average per capita MSW generation, as per survey results, was estimated at range of $0.25 \mathrm{~kg}_{\text {day }}{ }^{-1}$ in $\mathrm{KM}$ to $0.47 \mathrm{~kg}_{\text {day }}{ }^{-1}$ in $\mathrm{KMC}$. Based on these per-capita MSW generation figures and population for the year 2011, the total MSW generation of the five municipalities of Kathmandu Valley is estimated to be 620 metric tonnes day ${ }^{-1}$ or 226300 metric tonnes year $^{-1}$. The per capita MSW generation and total amount of MSW in each municipality of Kathmandu Valley is also given in Table 1. Five municipalities from Kathmandu Valley generates 310 metric tonnes day ${ }^{-1}$ household wastes, 271 metric tonnes day ${ }^{-1}$ commercial wastes and 39 metric tonnes day ${ }^{-1}$ institutional wastes respectively. Households in Nepal are the major solid waste generators as in other developing countries like Uganda (Okumu and Nyenje, 2011), India (Pattnaik and Reddy, 2010), Tanzania (Kaseva and Mbuligwe, 2005), Kenya (Henry et al., 2006) and Indonesia (Supriyadi et al., 2000).

Table 1. The MSW generation in each municipality of Kathmandu Valley

\begin{tabular}{|c|c|c|c|c|c|}
\hline Name of Municipality & KMC & LSMC & BM & MTM & KM \\
\hline Total Population (2011) & 1003285 & 226728 & 83658 & 84142 & 67171 \\
\hline Population density (persons $\mathrm{km}^{-2}$ ) & 20289 & 14966 & 12753 & 7574 & 4551 \\
\hline Average per capita $\mathrm{HH}$ waste $\left(\mathrm{kg} \mathrm{day}^{-1}\right)$ & 0.23 & 0.19 & 0.16 & 0.14 & 0.15 \\
\hline Total HH waste (metric tonnes day ${ }^{-1}$ ) & 233.07 & 42.15 & 13 & 11.5 & 10.19 \\
\hline $\begin{array}{l}\text { Total commercial waste (metric tonnes } \\
\text { day }^{-1} \text { ) }\end{array}$ & 203.49 & 36.8 & 13.8 & 10.04 & 5.93 \\
\hline $\begin{array}{l}\text { Total institutional waste (metric tonnes } \\
\text { day }^{-1} \text { ) }\end{array}$ & 29.58 & 5.35 & 2.02 & 1.46 & 0.86 \\
\hline Average per capita MSW $\left(\mathrm{kg} \mathrm{day}^{-1}\right)$ & 0.46 & 0.37 & 0.35 & 0.27 & 0.25 \\
\hline $\begin{array}{l}\text { Total MSW generation (metric tonnes } \\
\text { day }^{-1} \text { ) }\end{array}$ & 466.14 & 84.3 & 28.9 & 23.01 & 16.99 \\
\hline
\end{tabular}

The obtained average per capita MSW generation rates for municipalities of Kathmandu Valley were similar for municipalities/cities of low income countries and countries in South Asia for 
examples Kabul/Afghanistan $\left(0.37 \mathrm{~kg} \mathrm{day}^{-1}\right)$, Cape Haitian city/Haiti $\left(0.21 \mathrm{~kg}\right.$ day $\left.^{-1}\right)$, Puduchhery/India $\left(0.59 \mathrm{~kg} \mathrm{day}^{-1}\right)$ which have similar GDPs and infrastructure as Nepal but a different religious and cultural matrix (Forouhar and Hristovski, 2012; Phillippe and Culot, 2009; Pattnaik and Reddy, 2010).

\section{MSW composition and materials recovery potential}

The characteristics of MSW collected depend on various factors such as consumer patterns, food habits, cultural traditions of inhabitants, lifestyles, climate, and economic status. The average composition of MSW was computed by combining all three major sources (households, commercial establishments and institutions) of municipal solid wastes. The analysis of household waste composition indicates that the highest waste fraction is biodegradable matter in each municipality of Kathmandu Valley. Waste generated from offices, schools, and colleges were categorized as institutional wastes in which the dominant fraction is paper and paper products in all municipalities. Students' regular lunch/tiffin boxes, used notebooks and discarded white papers made higher fraction of paper and paper products in school. The amount of biodegradable waste in schools is comparatively low because of little consumption of fresh foods in schools. Shops, hotels, and restaurants were categorized as commercial establishments which mainly consist of plastics, papers and biodegradable wastes in composition. The high percentage of plastics was generally found in shops, while organic fraction was observed more in hotels and restaurants in all municipalities.

The average composition of MSW of Kathmandu Valley in eight major waste categories (with average values by \% wet weight), is represented graphically in Figure 2. As shown in Figure 2, the average MSW composition of Kathmandu Valley indicates that the highest waste fraction is biodegradable matter (54\%) followed by plastics (19\%). Papers and glass comprised 17\%, and $3 \%$ respectively. Metal, textiles, rubber and leather and others accounted for $2 \%$ or less.

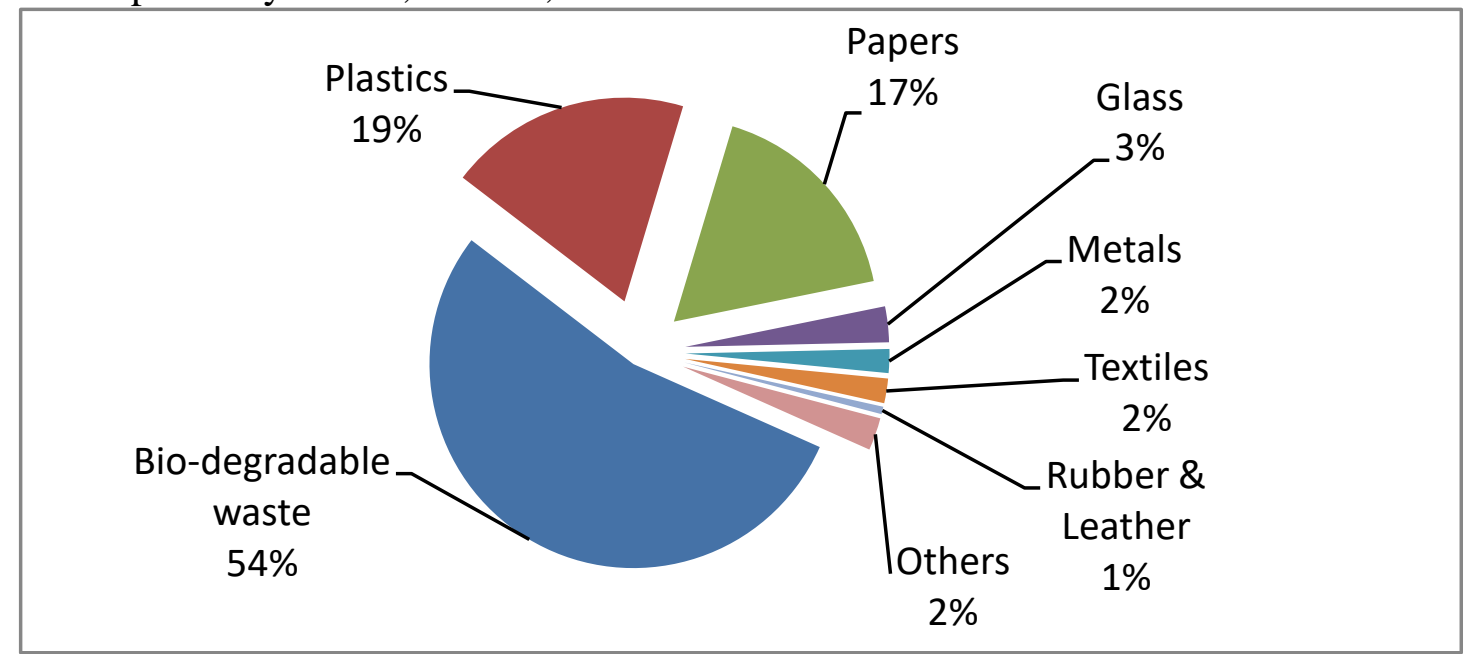

Figure 2. Average MSW composition of five Municipalities of Kathmandu Valley

The composition of municipal solid wastes in each municipality of Kathmandu Valley is shown in Figure 3. The proportion of biodegradable materials varies from 38\% (MTM) up to 69\% $(\mathrm{KM})$. The content on major reusable and recyclable materials (i.e., plastics, papers, metal and 
glass) varies from $30 \%(\mathrm{KM})$ to $45 \%$ (MTM). As far as the plastic waste is concerned, which is generally creating a major waste disposal problem in almost all municipalities of Kathmandu Valley, the value varies from 10\% (KM) to 20\% (MTM). The findings are in consistence with those of Visvanathan et al. (2004) that the solid waste composition in most Asian countries is highly biodegradable, mainly composed of food waste, and the remaining of paper, rubber/leather, wood/grass, metal, plastic/foam, glass and textiles. Xiao et al. (2007) showed that food waste comprises the highest proportion followed by plastic and paper in Beijing. The biodegradable portion was high in waste stream of Sri Lanka, followed by paper, plastic, glass and metal (Bandara et al., 2007). Forouhar and Hristovski (2012) also reported that the organic material comprised almost $70 \%$ of the collected solid waste composition in Kabul. It was found that about $65 \%$ constitute biodegradable type and the rest 35\% comprise non-biodegradable fraction (reusable and recyclable) of the total MSW in Pondicherry/India (Pattnaik and Reddy, 2010).

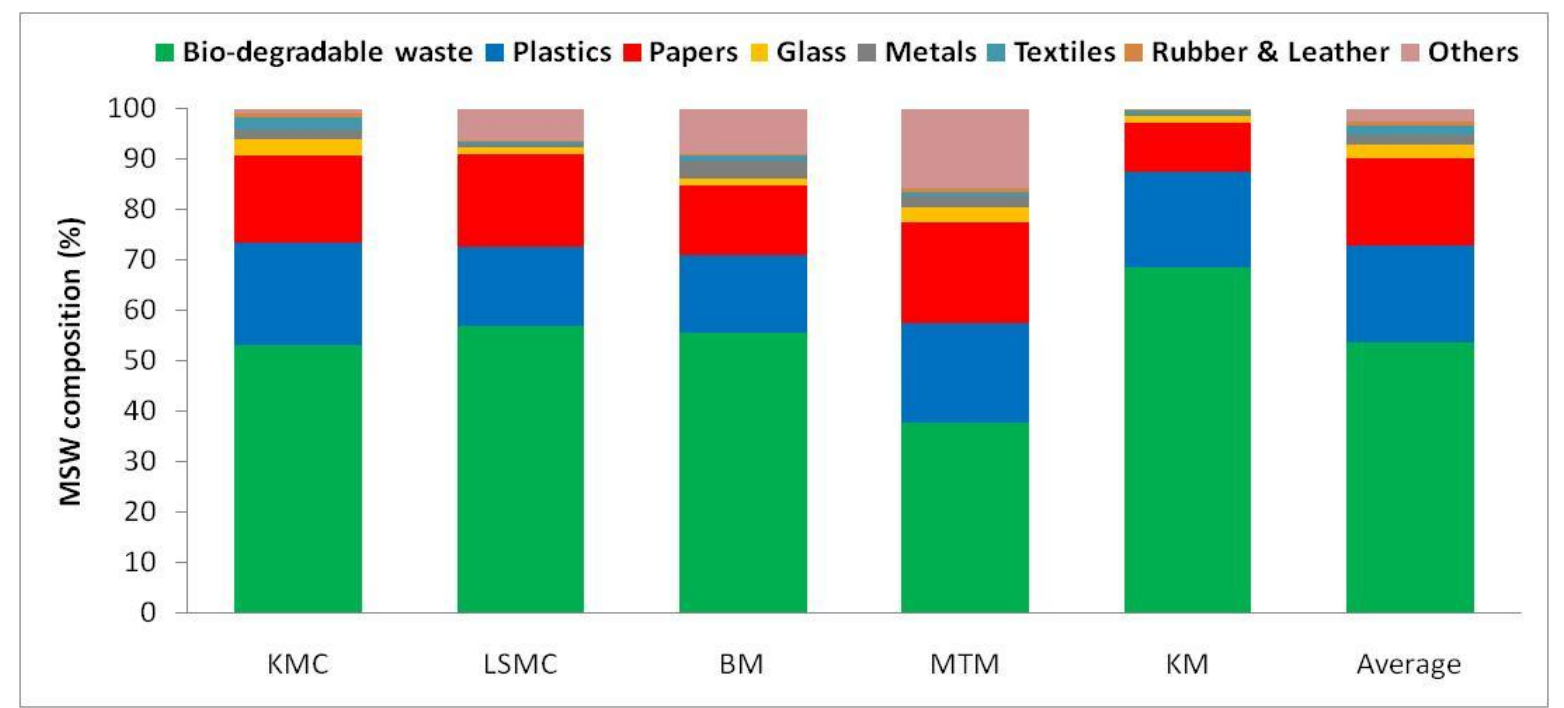

Figure 3. The average MSW composition in each municipality of Kathmandu Valley

The MSW composition of municipalities in Kathmandu Valley provides a great potential for material recovery which can be increased by promoting 3R (Reduce, Reuse and Recycle) practice. The content of major reusable and recyclable materials (i.e., plastic, papers, metal, glass, rubber and leather, and textiles) comprised with an average of $44 \%$ which is equivalent to 271 metric tonnes day ${ }^{-1}$. The recyclable and reusable materials are higher in municipalities of Kathmandu Valley when compared to cities of other developing countries: Cape Haitian city/Haiti: 26.6\% (Phillippe and Culot, 2009); Mostaganem/Algeria: 31.1\% (Guermoud et al., 2009); Amman/Jordan: 31\% (Abu-Qudais and Abu-Qdais, 2000).

\section{Current status of materials recovery from MSW}

Plastics, paper/paper products, metals (ferrous, non-ferrous metals), glass bottles are the main items which are reused and recycled in Kathmandu Valley. Others like textiles, rubbers, leather, batteries, and waste oil from automobiles are also recovered. Cycle hawkers collect materials from sources while waste pickers collect useful materials from dump site and sell to scrap shops. 
All the scrap shops that accumulate different types of more imperative recyclable and reusable materials mentioned above; further sort them and either sell reusable materials to consumers directly or supply to large scrap dealers.

Although 700 to 800 scrap shops were reported in Kathmandu Valley (Pathak, 2013; PRISM, 2013), all the scrap shops are not of same scale and do not receive the materials directly from cycle hawker/waste pickers or sources but receive from separated materials from other small scale scrap dealers. So, based on professional judgement during survey, 450 scrap shops those receive almost all the major reusable and recyclable materials from cycle hawkers/waste pickers or direct from sources, are counted for the estimation of total reusable and recyclable materials in Kathmandu Valley. Sorted recyclable fractions are then sold to large scrap dealers which are finally supplied to recycling industries. A generic diagram representing the flow of reusable and recyclable materials in Kathmandu Valley is shown in Figure 4.

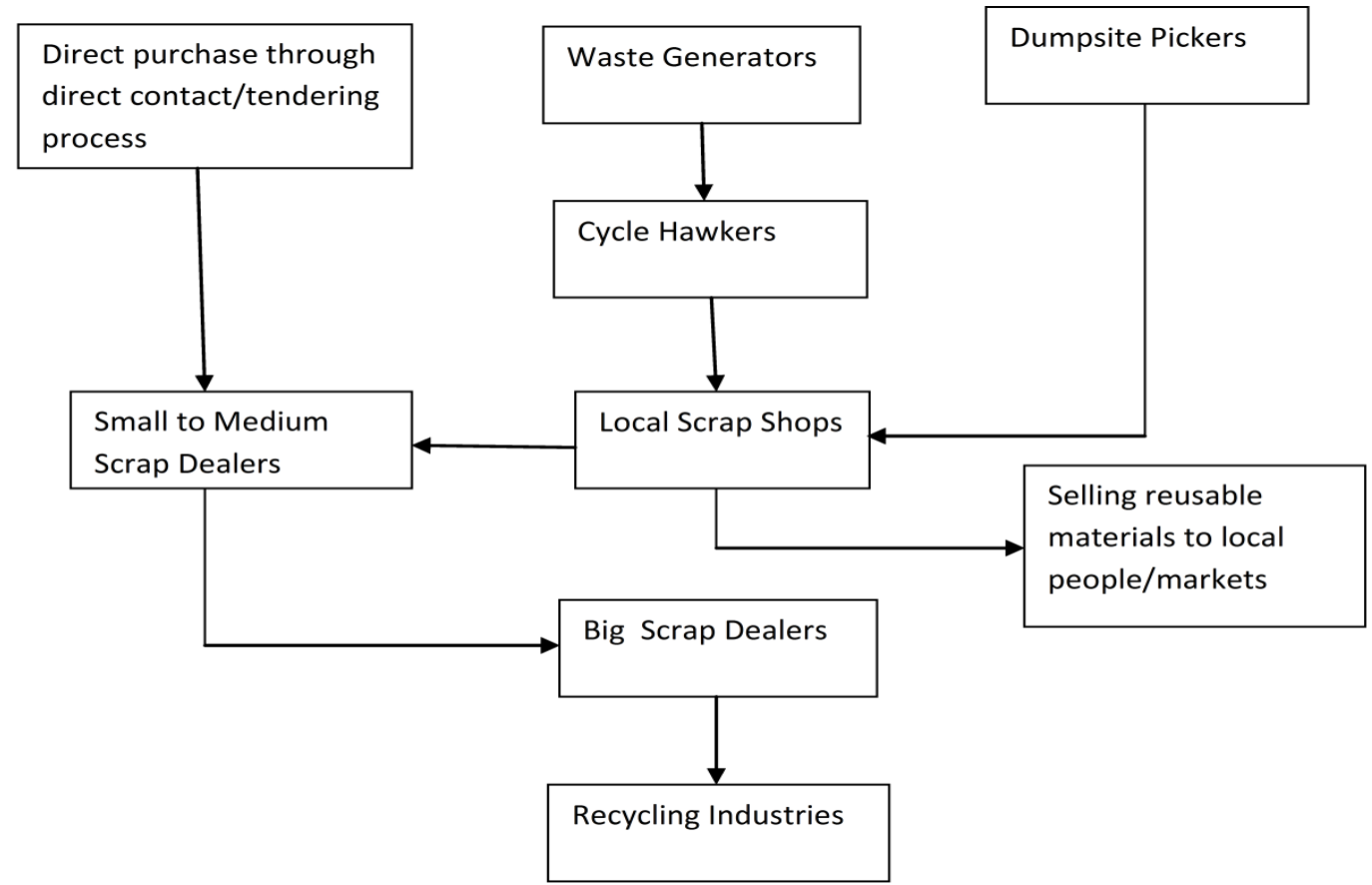

Figure 4. A generic diagram representing the flow of reusable and recyclable materials in Kathmandu Valley

The Table 2 shows a yearly average amount of main reusable and recyclable materials per scrap shop being currently recovered from MSW in Kathmandu Valley. Collectively, papers and their products comprise one of the largest recyclable/reusable fractions of MSW. The paper and paperboard materials category includes products such as office papers, newspapers, books, notebooks, cartons, tissue paper, paper plates and cups. Paper and paper products are one of the most common materials for each scrap shops. Although a part of collected cartons are reused, other paper/paper products are sent to paper recycling industries. This study revealed that more than 40 metric tonnes day ${ }^{-1}$ papers are being recovered from MSW in Kathmandu Valley as shown in Table 2. 
Table 2. Average materials per scrap shop and total amount of recovered materials from MSW in Kathmandu Valley

\begin{tabular}{|c|l|c|c|c|c|}
\hline S.N. & $\begin{array}{l}\text { Main recovered } \\
\text { materials from } \\
\text { solid waste } \\
\text { stream }\end{array}$ & $\begin{array}{l}\text { Sample } \\
(\mathrm{n})\end{array}$ & $\begin{array}{l}\text { Average yearly } \\
\text { recovered } \\
\text { materials per } \\
\text { shop (metric } \\
\text { tonnes) }\end{array}$ & $\begin{array}{l}\text { Total amount of } \\
\text { yearly recovered } \\
\text { materials (metric } \\
\text { tonnes) }\end{array}$ & $\begin{array}{l}\text { Total amount of } \\
\text { daily recovered } \\
\text { materials(metric } \\
\text { tonnes) }\end{array}$ \\
\hline 1 & Plastic & 99 & 16.3 & 7335.0 & 20.1 \\
\hline 2 & Paper & 82 & 33.1 & 14895.0 & 40.8 \\
\hline 3 & Metal(iron, tin) & 97 & 40.6 & 18270.0 & 50.1 \\
\hline 4 & Aluminum & 55 & 0.4 & 180.0 & 0.5 \\
\hline 5 & Glass & 89 & 20 & 9000.0 & 24.7 \\
\hline 6 & Battery & 68 & 3.4 & 1530.0 & 4.2 \\
\hline
\end{tabular}

Plastics are found in all major MSW categories, the containers and packaging category (bags, sacks, and wraps, other packaging, PET bottles, jars and HDPE natural bottles and other containers). As the production of plastic is in growing pattern, the rate of recycling is relatively small as compared to other materials. Generally, paper, paper products, metals and glass are usually sorted at sources before supply to scrap shops, but, majority of the plastic fractions go to dump site as mixed waste rather than recovery from sources which results the lower recovery rate as compare to other scrap materials. Currently, a total of 20 metric tonnes day ${ }^{-1}$ plastic is being recovered from MSW for recycling in Kathmandu Valley.

By weight, ferrous metals are the largest category of metals in MSW of Kathmandu Valley (Table 2). Durable goods such as appliance, furniture, tires, containers and packaging are the source of ferrous metals in MSW. Large quantities of ferrous metals are found as a part of construction materials and transportation vehicle parts and products, such as automobiles, and locomotives, but most of these are usually reused and remaining limited fraction are sent for recycle. In addition to ferrous metal, tin is another largest category of metals collected by scrap shops which is usually recycled. Table 2 shows the total ferrous metal and tin collected in scrap shop estimated to be more than 50 metric tonnes day ${ }^{-1}$ in Kathmandu Valley. The source of aluminum in MSW is aluminum cans which are usually recovered. Aluminum cans were recovered at a rate of 0.4 metric tonnes year ${ }^{-1}$ per scrap shop (Table 2). A half ton of aluminum can is currently being recovered in Kathmandu Valley. Other non-ferrous metals (e.g., lead, copper, and alloy) are more precious and found in durable products such as appliances, consumer electronics, etc. Lead in lead-acid batteries is the most prevalent non-ferrous metal (other than aluminum) in MSW. Note that only lead-acid batteries from passenger cars, trucks, and motorcycles are included. Based on interview with main scrap dealer, these non-ferrous metals including aluminum are estimated to be 5 metric tonnes day ${ }^{-1}$ in Kathmandu Valley which is usually sent for recycling.

Glass is generally found in MSW primarily in the form of containers. In the container category, glass is found in the form of liquor bottles, and jars for food, and other products. Recovered glass containers (bottles) are used to make new glass containers and other uses such as fiberglass insulation, aggregate, and glassphalt (a variety of asphalt that uses crushed glass) for road 
construction (USEPA, 2010). Recovery of glass bottles was found at 20 metric tonnes year ${ }^{-1}$ per shop as shown in Table 2. Therefore, the amount of total glass bottles that are currently being recovered was nearly 25 metric tonnes day ${ }^{-1}$ in Kathmandu Valley (Table 2).

Recycling batteries recovers the valuable metals and saves energy by reducing the need for raw materials. Almost all parts of batteries are recycled except acid and toxic materials inside them. During the survey, it was found that almost all surveyed scrap shops receive battery for recycling. The analysis revealed that about 4 metric tonnes day ${ }^{-1}$ of battery is being recovered in Kathmandu Valley (Table 2).

Based on recovered reusable and recyclable figures per scarp shops as given in Table 2 and number of scrap shops for the year 2013, materials like plastics, papers, metals, glass and battery in Kathmandu Valley are being recovered to 140 metric tonnes day ${ }^{-1}$ or 51210 metric tonnes year $^{-1}$. Other materials like textiles, rubber and leathers and waste oils from automobiles are also collected to recycle. The study showed the increasing trend of recovery of materials from MSW in Kathmandu Valley when compared with 100 metric tonnes day ${ }^{-1}$ reported by Nippon Koei \& Yachiyo Engineering (2005).

\section{Conclusions and Recommendations}

This study assessed MSW generation and composition to estimate the material recovery potential and the amount of reusable and recyclable materials that is being collected in Kathmandu Valley. The study showed that content of major reusable and recyclable materials comprised with an average of $44 \%$ (271 metric tonnes day ${ }^{-1}$ ), which provides a great potential for material recovery. Out of 271 metric tonnes day ${ }^{-1}$ of reusable and recyclable materials, only 140 metric tonnes day ${ }^{-1}$ was recovered in 2013, which is higher than the previous recovery and recycling rate; 100 metric tonnes day ${ }^{-1}$ in 2005. This increasing trend of material recovery reduces burden on natural resources, processing cost of virgin materials and also saves operation costs for final disposal. In addition to this, it facilitates in reduction of environmental risks by reducing the amount of waste to be disposed off at landfill site.

Although, no formal municipal waste recovery and recycling programs is practiced at present, informal recycling practice within low-income groups exists in Kathmandu Valley where, reusable and recyclable materials are collected through these informal waste pickers and sold to local scrap shops for income generation and livelihood. The output of this study would be useful to develop sustainable strategies to promote recycling business which should be socially desirable, economically viable, and environmentally sound.

Acknowledgements: This study was financially supported by Asian Development Bank (ADB) and Solid Waste Management Technical Support Center (SWMTSC).

\section{References}

Abu-Qudais MD, Abu-Qdais HA. Energy content of municipal solid waste in Jordan and its potential utilization. Energy conversion and management 2000; 41: 983-991.

Agarwal A, Singhmar A, Kulshrestha M, Mittal AK. Municipal solid waste recycling and associated markets in Delhi, India. Resources, Conservation and Recycling 2005; 44: 73-90. 
Agunwamba JC. Analysis of scavengers' activities and recycling in some cities of Nigeria. Environmental Management 2003; 32: 116-127.

Alamgir M, McDonald C, Roehi KE, \& Ahsan A. Integrated management and safe disposal of MSW in least developed Asian countries-a feasibility study. Waste Safe Khulna University of Engineering and Technology, Asia Pro Eco Programme of the European Commission 2005.

Asim M, Batool SA, Chaudhry MN. Scavengers and their role in the recycling of waste in Southwestern Lahore. Resources, Conservation and Recycling 2012; 58: 152-162.

Bandara NJ, Hettiaratchi JPA, Wirasinghe SC, Pilapiiya S. Relation of waste generation and composition to socio-economic factors: a case study. Environmental Monitoring and Assessment 2007; 135: 31-39.

Chang YM, Liu CC, Dai WC, Hu A, Tseng CH, Chou CM. Municipal solid waste management for total resource recycling: a case study on Haulien County in Taiwan. Waste Management \& Research 2013; 31: 87-97.

Dangi MB, Pretz CR, Urynowicz MA, Gerow KG, Reddy, JM. Municipal solid waste generation in Kathmandu. Nepal. Journal of environmental management 2011; 92: 240-249.

Dangi MB, Urynowicz MA, Gerow KG, Thapa RB. Use of stratified cluster sampling for efficient estimation of solid waste generation at household level. Waste Management \& Research 2008; 26: 493-499.

Forouhar A, Hristovski KD. Characterization of the municipal solid waste stream in Kabul, Afghanistan. Habitat International 2012; 36: 406-413.

Gallardo A, Bovea MD, Colomer FJ, Prades M, Carlos M. Comparison of different collection systems for sorted household waste in Spain. Waste Management 2010; 30: 2430-2439.

Guermoud N, Ouadjnia F, Abdelmalek F, Taleb F. Municipal solid waste in Mostaganem city (Western Algeria). Waste Management 2009; 29: 896-902.

Gutberlet J. Recycling citizenship, recovering resources: urban poverty reduction in Latin America. Aldershot: Ashgate 2008; p. 163.

Hayami Y, Dikshit AK, Mishra SN. Waste pickers and collectors in Delhi: poverty and environment in an urban informal sector. The Journal of Development Studies 2006; 42: 41-69.

Henry RK, Yongsheng Z, Jun D. Municipal solid waste management challenges in developing countriesKenyan case study. Waste management 2006; 26: 92-100.

Hoornweg D, Bhada-Tata P. What a waste: a global review of solid waste Management. Urban Development Series Knowledge Papers. World Bank 2012.

Huysman S, Debaveye S, Schaubroeck T, De Meester S, Ardente F, Mathieux F, Dewulf J. The recyclability benefit rate of closed-loop and open-loop systems: A case study on plastic recycling in Flanders. Resources, Conservation and Recycling 2015; 101: 53-60.

Kaseva ME, Gupta SK. Recycling - an environmentally friendly and income generating activity towards sustainable solid waste management. Case study_Dar es Salaam City, Tanzania. Resources, Conservation and Recycling 1996; 17: 299-309.

Kaseva ME, Mbuligwe SE. Appraisal of solid waste collection following private sector involvement in Dar es Salaam city, Tanzania. Habitat International 2005; 29: 353-366.

Kawai K, Osako M, Matsui S. Identification of junk buyers' contribution to recycling of household waste in Hanoi, Vietnam, through a physical composition analysis. Waste Management \& Research 2012; 30: 681-688.

Kocasoy G. Solid Waste Management in Developing Countries: Proposed Amendments in the existing situation. In: Proceedings, Sardinia 2001. Eighth International Waste Management and Landfill Symposium, 1-5 October, Margherita di Paula, Cagliary, Italy 2001

Linzner R, Salhofer S. Municipal solid waste recycling and the significance of informal sector in urban China. Waste Management \& Research 2014; 32: 896-907. 
Mancini SD, Nogueira AR, Kagohara DA, Schwartzman JAS, de Mattos T. Recycling potential of urban solid waste destined for sanitary landfills: the case of Indaiatuba, SP, Brazil. Waste Management \& Research 2007; 25: 517-523.

Medina M. Scavenger cooperatives in Asia and Latin America. Resources, Conservation and Recycling 2000; 31: 51-69.

Mitchell CL. Altered landscapes, altered livelihoods: The shifting experience of informal waste collecting during Hanoi's urban transition. Geoforum 2008; 39: 2019-2029.

Nippon Koei P. Ltd, Yachiyo Engineering P. Ltd. The Study on the Solid Waste Management for the Kathmandu Valley, Final Report (Clean Kathmandu Valley - CKV- Study). Kathmandu: Ministry of Local Development, His Majesty's Government of Nepal; Japan international Cooperation Agency (JICA) 2005.

Nzeadibe TC. Solid waste reforms and informal recycling in Enugu urban area, Nigeria. Habitat International 2009; 33: 93-99.

Ojeda-Benitez S, Armijo-de-Vega C, Ramírez-Barreto ME. Formal and informal recovery of recyclables in Mexicali, Mexico: handling alternatives. Resources, Conservation and Recycling 2002; 34: 273288.

Okot-Okumu J, Nyenje R. Municipal solid waste management under decentralisation in Uganda. Habitat International 2011; 35: 537-543.

Pathak DR, Yatabe R, Bhandary NP. Identification of major factors affecting spatial and temporal variation on water quality in Kathmandu basin, Nepal using multivariate statistical analysis. International Journal of Water 2015; 9: 209-225.

Pathak RH. Personnel communicitaions, January, 2013.

Pattnaik S, Reddy MV. Assessment of municipal solid waste management in Puducherry (Pondicherry), India. Resources, Conservation and Recycling 2010; 54: 512-520.

Philippe F, Culot M. Household solid waste generation and characteristics in Cape Haitian city, Republic of Haiti. Resources, Conservation and Recycling 2009; 54: 73-78.

PRISM (2013) Poverty Reduction of Informal Workers in Solid Waste Management $\quad$ (PRISM), Nepal, Practical Action Publications (2013):http://practicalaction.org/poverty- reduction-ofinformal-workers-in-solid- waste-management-prism-nepal (Accessed in April 25, 2015).

Sasaki S, Araki T. Estimating the possible range of recycling rates achieved by dump waste pickers: The case of Bantar Gebang in Indonesia. Waste Management \& Research 2014; 32: 474-481.

Sembiring E, Nitivattananon V. Sustainable solid waste management toward an inclusive society: Integration of the informal sector. Resources, Conservation and Recycling 2010; 54: 802-809.

Serrona KRB, Yu J, Aguinaldo E, Florece LM. Developing a monitoring and evaluation framework to integrate and formalize the informal waste and recycling sector: The case of the Philippine National Framework Plan. Waste Management \& Research 2014; 32: 882-895.

Solid Waste Management and Resource Mobilization Center (SWMRMC). A diagnostic report on state of solid waste management in municipalities of Nepal, SWMRMC, Pulcowk, Nepal 2004.

Solid Waste Management Technical Support Centre (SWMTSC). Solid Waste Management Act (SWMA, 2011), SWMTSC, Kathmandu 2011.

Supriyadi S, Kriwoken LK, Birley I. Solid waste management solutions for Semarang, Indonesia. Waste management and Research 2000; 18: 557-566.

USEPA. Municipal Solid Waste in the United States: 2009 Facts and Figures, USEPA, USA. December 2010.

Velis CA, Wilson DC, Rocca O, Smith SR, Mavropoulos A, Cheeseman CR. An analytical framework and tool ('InteRa') for integrating the informal recycling sector in waste and resource management systems in developing countries. Waste Management \& Research 2012; 30: 43-66.

Visvanathan C, Tränkler J, Kurian J, Chiemchaisri C, Basnayake BFA, Gongming Z. Municipal Solid Waste Management in Asia: Asian Regional Research Program on Environmental Technology. ISBN, 974-417-258. AIT Publication, Thailand 2004; Available at: http://www.swlf.ait.ac.th/. 
Wilson D.C. Development drivers for waste management. Waste Management \& Research 2007; 25: 198-207.

Wilson D.C, Araba AO, Chinwah K, Cheeseman CR. Building recycling rates through the informal sector. Waste Management 2009; 29: 629-635.

Xiao Y, Bai X, Ouyang Z, Zheng H, Xing F. The composition, trend and impact of urban solid waste in Beijing. Environmental monitoring and assessment 2007; 135: 21-30. 